\title{
The Chosen Village Head Leadership in Carrying Out Government Duties: Analysis Study of Sidoharjo Village Head, Susukan, Semarang
}

Musta'an

Sahid University of Surakarta, Indonesia Corresponding email: mustaan57@gmail.com

\begin{abstract}
:
This study is entitled Leadership of Selected Village Heads in Carrying Out Government Duties (Analysis Study of Sidoharjo Village Head, Susukan District). The focus of this research is about how the Village Chief Leadership Style in Sidoharjo Village Head, Susukan District and the purpose of this study is to find out the Village Head Leadership Style in Sidoharjo Village Head, Susukan District. This study is classified as a descriptive study with core questionnaire instruments and data analysis techniques using the presentation of the frequency table of the results of questionnaires from respondents who have been determined based on questions about the 4 leadership styles based on expert theory used as grand theory in this study. The results showed that the leadership style that tends to be applied by village heads in carrying out their daily tasks and functions is the leadership style of Democracy. Democratic leadership style can be seen from the involvement or active participation of Sidoharjo village head in deciding problems in every activity of the organization / office. In addition, the Village Head also prioritizes democracy in his administration by always holding deliberations to reach consensus in making every decision.
\end{abstract}

\section{Keywords:}

Leadership style, a village head, government duty

JEL: $A 30, A 31, B 00$

\section{INTRODUCTION}

Leadership in organizations is a process in which a leader influences and sets an example for followers in an effort to achieve organizational goals. A good leader is not seen from how many people become followers, nor is it seen from how long he leads. A good leader is seen from how much he is able to create a new leader. Leaders have a very vital role in the course of government organizations, this is very determining the course of government. Leadership can be said as a way of a leader in directing, encouraging and managing all the elements in the group or organization to achieve the desired organizational goals so as to produce maximum employee performance.

In general terms, especially in management, leadership is often referred to as the Leader. There are several definitions of leadership, among others: geetting things done, that is, achieving results through others, moving others to achieve desired work, leadership is influence, nothing more or nothing less, so leadership is one word ie Influence means to influence, motivate, directing others to achieve organizational goals. The role of leaders is so vital and important in developing an institution / organization, both private and public, the 
research aims to make a study of the leadership style of village head in the Sidoharjo subdistrict of Susukan, with the research title being as follows: Leadership of Selected Village Heads in Carrying Out Government Duties (Study Analysis of Sidoharjo Village Head, Susukan District). Based on the background outlined above, the problems that will be the focus of this research are as formulated in the formulation of the problem: How is the Leadership Style of the Chosen Village Chief in Carrying Out Governmental Tasks (Analysis Study of Sidoharjo Village Head, Susukan District).

The purpose of this study was to determine the Leadership of the Elected Village Head in Carrying Out Government Duties (Analysis Study of Sidoharjo Village Head, Susukan District). Usability Research, consisting of theoretical benefits that are expected to increase and broaden scientific insights; in particular, in terms of leadership style and practical benefits, it is expected to be able to provide knowledge, input or contribute thoughts for the village headmanship in the Sidoharjo sub-village, the susukan sub-district in general.

\section{LITERATURE REVIEW}

\section{Leadership}

According to Hemhiel and Coons (1957), the definition of leadership is the behavior of individuals in the leadership of various organizations or groups in achieving common goals (shared goals). Meanwhile, according to Terry, in Siagian (2002), leadership is a senior in interacting with others in order to be facilitated, so that all the goals set by the leaders and all team members. Basically leadership, abilities and activities in the organization with the aim that followers want to do what the leaders want. Thus, it can be ascertained that leadership is a process to influence others (Rivai, 2004: 38). Meanwhile, Moejiono, in Siahaan (2008) which focuses on leadership, actually, as related to one direction, is demanded to improve the quality of certain qualities that remember him with his followers. Meanwhile, according to Jacobs and Jacques (1990: 281) the meaning of leadership is a process of giving meaning to collective effort, so there is a willingness to make the desired effort to achieve goals.

According to Wahjosumidjo (1987) the notion of leadership is the ability that exists in a leader that contains certain traits, such as: personality (personality), ability (ability), ability (ability. Leadership style and behavior of the leader, and interaction between leaders, followers and interactions. According to Hasibuan (2000), leadership is a strategy carried out by someone in order to influence someone / many people to want to do something useful for the progress of the organization. Meanwhile, Siagian (2002) defines leadership as the ability to influence a group towards the achievement of goals. Meanwhile, Rivai (2001) explains that the process produces a large influence in setting organizational goals, motivating participation motivation to achieve goals, influencing to improve the culture of followers, as well as the process of linking to positive activities that have to do with work within the organization. From some of the understanding of the experts above can refute leadership abilities that have the ability possessed by people in making an effort so that members voluntarily do things that are a common goal for the achievement of organizational goals. With a good leadership process, it is expected that a good organizational process will also be created, and organizational progress can be created and carried out properly and professionally. If everything is created properly and professionally then the goals set by the organization will be easily achieved. 


\section{Leadership Style}

Leadership style is a special style / behavior that someone has in influencing others to do something. A person's leadership style varies depending on one's character and level of maturity. One's leadership style is considered as one's leadership style which is identical to the type of leadership possessed by Siagian (2003). Leadership style that has a unique style, character and specialization determined by others depends on the character / character of the person. One's leadership style is very opposed to the success of subordinates in carrying out the targets that have been set, and the sound is in the success of the organization in achieving goals that have been mutually agreed upon.). Meanwhile, Rivai (2004) describes leadership styles that form patterns that tend to favor and are often applied by leaders in carrying out their leadership strategies in order to achieve organizational goals.

Thus, the leadership style is the pattern of policies and strategies needed and often applied by leaders, by uniting organizational goals with all objectives, to achieve the goals that have been achieved together with an organization. The right leadership style will make the organization will increase significant Progress in its management.

So, to be able to determine the leadership style is the basic character requested by each leader in the leadership of the leader to run the wheels of government both in government organizations, private companies and government education. According to Arep and Tanjung (2003), there are 4 (four) types of leadership styles, namely democracy, dictatorship, Paternalism, and Free Rein or Laissez Faire.

\section{RESEARCH METHODS}

This type of research is analytical descriptive research, in analyzing the leadership style of the selected Village Head in Sidoharjo Village, Susukan District, Semarang Regency through distributing questionnaires to the employees in Sidoharjo Hamlet, Susukan District. The populations in this study were all employees of the Village office of Sidoharjo, Susukan District, as many as 16 people. While, the sampling technique in this study uses total sampling, which amounted to 16 respondents. The data collected in this study were sourced from primary data obtained using quantitative and qualitative approaches.

\section{RESULTS AND DISCUSSION}

\section{Democratic Leadership Style}

In getting data from the Democratic leadership style, 2 (two) questions were asked to respondents, which involved: (i) whether the Village Head prioritizes deliberation to reach consensus in every decision making. (ii) Whether the Village Head participated in every activity of the organization / office Below is the result of a questionnaire from the two questions above.

Th questionnaire results from the list of questions whether the Village Chief prioritizes deliberation to reach consensus in every decision making, the data in the table above explains that of 16 respondents, $37.5 \%$ (6 respondents) of whom stated that the Village Chief very often prioritized deliberation for consensus in each decision decisions, $25 \%$ (4 respondents) others answered frequently, 18.75\% (3 respondents) others stated quite often, 
while $12.5 \%$ (2 respondents) gave rare answers, and $6.25 \%$ (1 respondent) said no ever, with an average score of respondents' answers to this question equal to 3.69 , the results show at intervals of $3.43-4.23$; where, respondents' answers or ratings are categorized as "good".

Regarding the question of whether the Village Head participated in every organizational / office activity, as can be seen in the table above, that out of 16 respondents, $50 \%$ (8 respondents) of them stated that the Village Head participated very often in every organizational / office activity, 31 , 25\% (5 respondents) answered often, $12.5 \%$ (2 respondents) stated quite often; while $6.25 \%$ (1 respondent) others gave rare answers, and none of the respondents stated never, with an average score of respondents' answers to this question equal to 3.93, which was at intervals of $3.43-4,23$; by looking at the results of the table the results of the answers or ratings of respondents can be categorized in the "good" category. Based on these results, the average number of respondents' answers to the Democratic leadership style indicators can be seen in the table below:

Table 1. The average number of respondents' answers to the Democratic leadership style indicators.

\begin{tabular}{|c|l|c|}
\hline No & \multicolumn{1}{|c|}{ Questions } & Score \\
\hline 1 & $\begin{array}{l}\text { Does the Village Head participate in any organizational } \\
\text { activities/office. }\end{array}$ & 3,93 \\
\hline 2 & $\begin{array}{l}\text { Does the Village Head prioritize deliberation to reach consensus in } \\
\text { every decision making. }\end{array}$ & 3,69 \\
\hline Amount & 7,62 \\
\hline Average & Good \\
\hline Category
\end{tabular}

Referring to the table above, it can be seen that the average number of respondents' answers to questions on the Democratic leadership style indicators is 3.81 , which is an interval of $3.43-4.23$; therefore the answers or ratings of respondents to this leadership style indicator can be categorized in the "good" category.

\section{Dictatorial or Autocratic Leadership Style}

Whereas, regarding the question of whether the Village Head tends to give orders to employees / subordinates by force, the table above explains that of the 16 respondents, no one answered very often for that question, $6.25 \%$ ( 1 respondent) stated often, $12,5 \%$ (2 respondents) give answers quite often; while $43.75 \%$ (7 respondents) stated rarely, and $37.5 \%$ (6 respondents) others said that the Village Head never gave orders to employees / subordinates by force, with an average score of respondents' answers to this question amounting to 1.88 , which is in the interval $1.81-2.61$; where, respondents' answers or ratings are categorized as "poor"

Referring to the list of questions asked to respondents above whether the Village Head relied more on strength / power in carrying out their duties and functions, the data in the table above explains that of the 16 respondents, none of them gave very frequent answers to these questions, $6.25 \%$ ( 1 respondent) stated frequently, $12.5 \%$ (2 respondents) others answered quite frequently, while $25 \%$ (4 respondents) stated rarely, and $56.25 \%$ (9 respondents) others gave answers that the Village Head had never relied on the power of power in carrying out its tasks and functions, the average score of respondents' answers to this question is 1.68, which is at intervals of 1-001-1.80; thus the respondent's answer or 
judgment is categorized as "not good". Thus, the average number of respondents' answers to indicators of the leadership style of the Dictator or Autocracy is, as follows.

Referring to the results above, it can be concluded that the average number of respondents' answers from the list of questions raised against the questions on the indicators of the leadership style of the Dictator or the Autocracy is 1.78, which is in the interval $1.00-1.80$; thus, respondents' answers or ratings on indicators in this leadership style can be categorized as "not good".

\section{Paternalistic Leadership Style}

Meanwhile, with regard to the question of whether the Village Head always provides protection (even seems excessive) to employees / subordinates, the data in table 4.10 above explains that from as many as 16 respondents, none of them gave very frequent answers to these questions, as did the answered often, also not available, $6.25 \%$ (1 respondent) stated quite often; meanwhile, 37.5\% (6 respondents) gave rare answers, and $43.75 \%$ (7 respondents) stated that the Village Head never gave excessive protection to the employees / subordinates, with the average score of respondents' answers to this question of 1.81, these results are entered at intervals of 1-001-1.80; Based on the answers or assessments of respondents who have done the results can be categorized as "not good". From the list of questions covering whether in carrying out his leadership, the village head tends to consider the employee / subordinate as a minor, the table above can be seen that from as many as 16 respondents, no one gave answers very often to that question, as well as those who stated often, also not, $12.5 \%$ (2 respondents) answered quite often; meanwhile, $43.75 \%$ (7 respondents) stated rarely, and $43.75 \%$ (7 respondents) others gave the answer that the Village Head had never acted like a "father", who considered the employee / subordinate to be a minor, with an average the average score of respondents' answers to this question is 1.68 , which is in the interval $1.00-1.80$; where, respondents' answers or ratings are categorized as "not good".

Table 2. The average number of respondents' answers to the Paternalistic leadership style indicators

\begin{tabular}{|c|c|c|}
\hline No & \multicolumn{1}{|c|}{ Questions } & Score \\
\hline 1 & $\begin{array}{l}\text { Does the village head tend to act as a "father", who considers the } \\
\text { employee / subordinate to be a minor? }\end{array}$ & 1,68 \\
\hline 2 & $\begin{array}{l}\text { Does the village chief always provide protection (even over- } \\
\text { impressed) to employees / subordinates }\end{array}$ & 1,81 \\
\hline Amount & 3,49 \\
\hline Average & 1,74 \\
\hline Category & Poor \\
\hline
\end{tabular}

Looking at the average results in the table above, it can be seen the average number of respondents' answers to the list of questions raised in the Paternalistic leadership style indicator is 1.74, which corresponds to the interval 1.81-2.61; where, the respondent's response or response to this leadership style indicator can be categorized as "poor".

\section{Free Rein or Laissez Faire Leadership Style}

Does the Village Head always coordinate with the employees / subordinates regarding the implementation of tasks / work, obtained results from as many as 16 respondents, no one gives answers very often to these questions, as well as those who answer often, also no, 
$31.25 \%$ ( 5 respondents) stated quite often; meanwhile, 37.5\% (6 respondents) gave rare answers, and $31.25 \%$ (5 respondents) stated that the Village Head had never coordinated with employees / subordinates regarding the implementation of tasks / work, with an average score of respondents' answers to questions this is 2.06, which is in the interval $1.81-2.61$; with the results above, it can be obtained that the results can be categorized in the "bad" category.

Based on the list of questions whether the Village Head delegated all tasks and responsibilities to employees / subordinates, table 4.13 above explained that of the 16 respondents, $6.25 \%$ ( 1 respondent) among them stated that the Village Chief very often delegated tasks and responsibilities to employees / subordinates, 6.25\% ( 1 respondent) answered frequently, $6.25 \%$ (1 respondent) stated quite often; meanwhile, $31.25 \%$ (5 respondents) others gave sparse answers, and 8 respondents (50\%) who stated never, seeing the average score of respondents' answers to questions in this leadership style amounting to 1.8, which is at intervals ; As for the assessment of respondents can be categorized in the category of "poor".

Table 3. Average number of respondents' answers to the Free Rein or Laissez Faire leadership style indicators.

\begin{tabular}{|c|l|c|}
\hline No & \multicolumn{1}{c|}{ Questionsn } & Score \\
\hline 1 & $\begin{array}{l}\text { Does the village head delegate tasks and responsibilities to } \\
\text { employees / subordinates? }\end{array}$ & 1,8 \\
\hline 2 & Does the village head always coordinate with the employees? & 2,06 \\
\hline Amount & 3,86 \\
\hline Average & 1,93 \\
\hline Category & Poor \\
\hline
\end{tabular}

Based on the data in the table above, it is known that the average number of respondents' answers to questions on the Free Rein or Laissez Faire leadership style indicators is 1.93, the results are at intervals of 2.62 - 3.42; by looking at the results of respondents' assessment of the indicators on this leadership style can be categorized in the category of "poor".

\section{Descriptive Percentage Analysis}

Table 4. Results of calculation of the average score of respondents' answers to each indicator of leadership style

\begin{tabular}{|c|l|c|c|c|}
\hline \multicolumn{1}{|c|}{ No Indicators } & Skcore & Category & Explanation \\
\hline 1 & Democracy Leadership style. & 3,81 & Good & Tend to be applied \\
\hline 2 & $\begin{array}{l}\text { Dictatorial or Autocratic leadership } \\
\text { style. }\end{array}$ & 1,78 & Nor Good & Not applied \\
\hline 3 & Paternalistic leadership style. & 1,74 & Poor & Not applied \\
\hline 4 & $\begin{array}{l}\text { Free Rein or Laissez Faire } \\
\text { leadership style. }\end{array}$ & 1,93 & Poor & Not applied \\
\hline
\end{tabular}

Based on the data in the above table, it can be clearly seen that the leadership style that tends to be applied by the Village Head of Sidoharjo Village in carrying out his daily tasks and functions is the Democratic leadership style. 


\section{Discussion}

Based on the calculation of the average score of respondents' answers to each leadership style, which is used as an indicator in this study, it is known that the leadership style that tends to be applied by the Village Head of Sidoharjo, Susukan District, Semarang Regency is the leadership style of Democracy. Democratic leadership style emphasizes more on the ability to creating consensus agreement. The leadership style is always focused on humans and guides its followers efficiently. The headman is always involved in government activities. Even so the subordinates are always given the opportunity of the Village Head to express their ideas and suggestions for progress and achieving the targets that have been carried. In addition, the Democratic leadership style adopted by the Village Head of Sidoharjo Village, Susukan District, Semarang Regency is also seen from his frequent emphasis on deliberation to reach consensus in every decision making; especially those related to organizational / office affairs.

The second leadership style is the dictatorial or autocratic leadership style. This leadership style is carried out by leaders who have a hard character in deciding something based on their own volition without involving subordinates. This type of leader uses his power to the full so that subordinates have no room to do anything. This leadership style is an authoritarian leadership style like in the time of the pharaohs. The leader is very dominant in every decision making and every policy, regulation, procedure is taken from his own idea. This type of leadership concentrates power on him. It limits the initiative and thinking power of its members. Authoritarian leaders will not pay attention to the needs of their subordinates and tend to communicate in one direction, from the top (leader) to the bottom (members). This leadership style tends not to be applied by the Sidoharjo hamlet in his leadership. This can be seen from the fact that the village head was never elected to use his position absolutely in making decisions. All of them are always based on the principles of deliberation and kinship as in the results of the questionnaire table.

Next is the Paternalistic Leadership Style. Paternalistic leadership style is a form between the style of democracy and dictatorship; which considers the subordinates have no power at all in decision making or action in daily performance. Although there is a democratic process, all must still be based on what was commanded by the leadership. The democratic process is merely a process of formality that is directed by the leadership to subordinates. This leadership style also tends not to be applied by the Village Head of Sidoharjo Subdistrict, Susukan District. Selected village heads tend to carry out democratic processes properly. Even the selected village head often entrusts / entrusts his work to his subordinates. This is proof that the village chief has put trust in his subordinates. The last is the Free Rein or Laissez Faire Leadership Style. This Leadership Style is a Leadership Style that is used by the Village Head of Sidoharjo Village, Susukan Sub-district, Semarang district. This leadership style is a style in which the leader gives full work to subordinates who are chosen in carrying out certain tasks. The Village Head only receives reports on the performance results from the designated subordinates. This Leadership Style is a typical leadership style that is carried out by the Village Head of Susukan Village, Semarang. The Village Head always conducts deliberations and supervision so that employee performance is always monitored. The leadership style of Free Rein or Laissez Faire, especially seen in the frequent Village Head delegate tasks and responsibilities to employees / subordinates. This has a good impact but there are also bad effects. Head who gives an abundance of work means the head gives appreciation to his subordinates. However, on the fact is that often the village head rarely supervises his subordinates, so often the task becomes less controlled. This causes the efficiency of the work to be reduced. 


\section{CONCLUSION}

The leadership style that tends to be applied by the chosen village head of the Sidoharjo sub-district of Susukan sub-district in carrying out its daily tasks and functions is a democratic leadership style. The democratic leadership style, among others, was demonstrated by the active participation of the Sidoharjo Village Head in every organizational / office activity with subordinates. In addition, the Village Head also often undertakes a democratic process by always providing a forum / deliberation activity so that subordinates can shed their ideas and ideas in determining decisions.

\section{REFERENCES}

A.A. Anwa, P. (2004). Manajemen Sumber Daya Manusia Perusahaan. Bandung: Remaja Rosdakarya.

Bungin, B. (2003). Analisis Data Penelitian Kualitatif. Jakarta: PT Raja Grafindo Persada,

Ishak, A. \& Hendri, T. (2003). Manajemen Motivasi. Jakarta: PT Grasindo.

Hasibuan, M. S.P. (2000). Manajemen Dasar, Pengertian dan Masalah. Jakarta: Bumi Aksara

Mangkunegara, M.S. (2007). Manajemen Sumber Daya Manusia. Yogyakarta: BPFEUGM,YKPN,

Rivai, V. (2004). Manajemen Sumber Daya Manusia untuk Perusahaan (Teori dan Praktek). Jakarta: Murai Kencana.

Sedarmayanti, (2001). Manajemen Sumber Daya Manusia. Bandung: PT. Refika Aditama.

Siagian, S.P. (2002). Manajemen Sumber Daya Manusia. Jakarta: Aksara Baru.

Toha, M. (2002). Kepemimpinan Dalam Manajemen. PT Raja Grafindo Persada.

Winardi. (2002). Kepemimpinan Dalam Manajemen. Jakarta: PT Rineka Cipta.

Yulk, G. (2001). Kepemimpinan Dalam Organisasi. Jakarta: Prehalindo. 